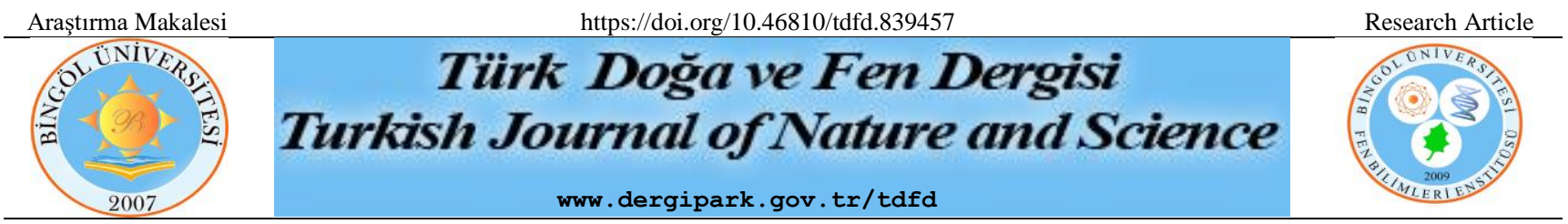

\title{
Investigation of the Effect of Fly Ash and Boron Waste Additive on Brick Structure Material
}

\author{
Hakan ÇAĞLAR ${ }^{*}$ \\ ${ }^{1 *}$ Kırşehir Ahi Evran University, Faculty of Engineering and Architecture, Department of Civil Engineering, Kırşehir, \\ Turkey
}

Hakan ÇAĞLAR ORCID No: 0000-0002-1380-8637

*Corresponding Author: c.hakan@ahievran.edu.tr

(Alınış: 12.12.2020, Kabul: 04.03.2021, Online Yayınlanma: 25.06.2021)

\begin{abstract}
Keywords
Boron waste,

Fly ash,

Brick,

Clay,

Baking

temperature

Abstract: The aim of this study was to produce bricks using boron waste of Eskişehir Kırka region and fly ash waste of Seyitömer thermal power plant. At the end of the study, it was aimed to produce bricks that are more durable than normal bricks, resistant to freeze-thaw and having thermal insulation properties in terms of physical and mechanical. 10\% boron waste was kept constant and 10\%, 20\% and 30\% fly ash were used in the bricks produced within the scope of the study. The study was carried out in three phases. In the first phase, bricks were produced using $100 \%$ clay soil and named as reference samples. In the second phase, doped brick production was carried out. The samples produced were baked at 800,900 and $1000{ }^{\circ} \mathrm{C}$. In the third and final phase, physical and mechanical experiments were applied to the brick samples produced. As a result, it was determined that fly ash and boron waste were not harmful to brick production and the optimum temperature was $900{ }^{\circ} \mathrm{C}$.
\end{abstract}

\section{Uçucu Kül ve Bor Atığı Katkısının Tuğla Yapı Malzemesi Üzerine Etkisinin Araştırılması}

\begin{abstract}
Anahtar
Kelimeler

Bor atığ 1 ,

Uçucu kül,

Tuğla,

Kil,

Pișirme

sicaklığ 1
\end{abstract}

\section{INTRODUCTION}

Brick are one of the oldest industries continuing since $8000 \mathrm{BC}[1,2]$. Brick is a block obtained by firing clay at certain temperatures [3]. It is exposed to 500-900 oC during the manufacture process, which could make the transformation of silicate crystal structureinto amorphous compounds [4]. Because of the availability of raw materials, environmental compatibility and their advantageous acoustic, thermal and mechanical properties, they are used as construction material worldwide [5]. It is a building material with a wide range due to its use in building walls [6].
One of the major disadvantages of traditional brick production is the rapid consumption of fertile soils in brick manufacturing [7-10]. For this reason, some countries such as China limit the use of clay in brick production to solve this problem [11].

Some researchers have studied brick production using different waste materials. Waste such as glass and boron waste can be used as an additive in brick production. Bricks with high compressive strength and low water absorption rate were produced by using glass waste [12]. Agricultural wastes such as sugarcane, scrub ash and rice husk ash can also be used in clay bricks $[13,14]$. In addition to agricultural waste, Industrial wastes such as 
fly ash, blast furnace slag, silica fume and boron waste are used as additives and substitutes in brick production [15].

Fly ash, which is an industrial waste used in the scope of the study and formed during the burning of coal, causes environmental pollution. Therefore, recycling of fly ash as a raw material for the construction industry has been a very beneficial solution in terms of economy and environment [16]. The properties of fly ash vary depending on the type of burnt coal, the type of combustion equipment used and the fly ash collection mechanism used [17]. Worldwide, approximately 600 million tons of fly ash is released annually [18]. It has been observed that substituting certain amounts of fly ash with clay improves the brick properties [19-27,1].

A large literature study has been conducted on the use of fly ash as a substitute in brick production [30, 25]. Bricks which is substitution fly ash have $10 \%$ lower unit weight compared to standard bricks [8]. Fly ash has the ability to increase compressive strength and reduce water absorption [6]. Leiva et al. [31] stated that the bricks showed a decrease in compressive strength with increased fly ash content below $1000{ }^{\circ} \mathrm{C}$ at baking temperature. Çiçek and Çinçin [30] revealed that the thermal properties of fly ash bricks were better than standard bricks. The edges of fly ash substituted bricks are smoother than standard bricks [8]. Fly ash can be used in brick production that is $10 \%$ lighter compared to clay bricks [31]. Fly ash also increases strength and decreases water absorption [32]. Many countries prefer fly ash instead of cement in concrete [33]. Also, standard brick production cost is $2 \%$ higher than fly ash substituted brick production cost [34]. Therefore, the use of fly ash in clay brick production is important in terms of cost effectiveness, strength and durability of bricks. In all of the studies, it has been observed that fly ash added bricks have higher water adsorption and lower wear resistance than standard bricks. It has also been reported that reinforced bricks have lower fire resistance and high porosity [35].

Another industrial waste used in the study is boron waste. Used boron waste was obtained from Kirka region of Eskişehir. It is understood that boron and boron wastes have a positive effect on the brick when substituted into the brick structure [36-40]. Boron wastes allow the use of cement, concrete, brick, tile etc. in the construction industry etc. [41, 42]. This enables both the assessment of boron wastes and the production of cheaper and quality building materials [42].

It was to produce bricks using boron waste of Eskişehir Kirka region and fly ash waste of Seyitömer thermal power plant. At the end of the study, it was aimed to produce bricks that are more durable than normal bricks, resistant to freeze-thaw and having thermal insulation properties in terms of physical and mechanical.

\section{MATERIAL AND METHOD}

\subsection{Material}

Fly Ash; The fly ash used in the study was obtained from Seyitömer thermal power plant. The chemical analysis of fly ash is presented in Table 1 . The specific gravity of fly ash is $1.58 \mathrm{~g} / \mathrm{cm}^{3}$, the specific surface area is $0.115 \mathrm{~m}^{2} / \mathrm{g}$ and the $\mathrm{pH}$ is 8.3. The fly ash used is also the type $\mathrm{F}$ fly ash, which has a lighter structure compared to other fly ashes.

Tablo 1. Chemical Analysis of Seyitömer fly ash [13]

\begin{tabular}{|c|c|}
\hline Component & $(\boldsymbol{\%})$ \\
\hline $\mathrm{SiO}_{2}$ & 52,34 \\
\hline $\mathrm{CaO}$ & 7,47 \\
\hline $\mathrm{MgO}$ & 5,75 \\
\hline $\mathrm{Fe}_{2} \mathrm{O}_{3}$ & 9,30 \\
\hline $\mathrm{Al}_{2} \mathrm{O}_{3}$ & 18,91 \\
\hline $\mathrm{Na}_{2} \mathrm{O}$ & 0,88 \\
\hline $\mathrm{K}_{2} \mathrm{O}$ & 2,17 \\
\hline $\mathrm{SO}_{3}$ & 2,25 \\
\hline $\mathrm{Na}_{2} \mathrm{O}(\mathrm{equ})$ & 2,31 \\
\hline Free CaO & 0,20 \\
\hline
\end{tabular}

Boron Waste; Boron waste used in the scope of the study and obtained from Eskişehir Kırka region, contain compounds such as $\mathrm{SiO}_{2}$, iron oxide $\left(\mathrm{Fe}_{2} \mathrm{O}_{3}\right)$ and magnesium oxide $\mathrm{MgO}$, which has binding properties at the rate of $12.8 \%$ (Table 2).

Table 2. Chemical properties of boron waste [39]

\begin{tabular}{|c|c|}
\hline Component & Boron waste (\%) \\
\hline $\mathrm{B}_{2} \mathrm{O}_{3}$ & 25 \\
\hline $\mathrm{CaO}$ & 10,38 \\
\hline $\mathrm{MgO}$ & 13,94 \\
\hline $\mathrm{SiO}_{2}$ & 12,98 \\
\hline $\mathrm{Na}_{2} \mathrm{O}$ & 5,67 \\
\hline $\mathrm{Al}_{2} \mathrm{O}_{3}$ & 0,96 \\
\hline $\mathrm{Fe}_{2} \mathrm{O}_{3}$ & 0,20 \\
\hline $\mathrm{K}_{2} \mathrm{O}$ & 0,72 \\
\hline Loss of Ignition & 29,15 \\
\hline
\end{tabular}

Clay; Clay soil used as the main material in the study and whose clay mineralogy was given in Table 3 was obtained from Taşköprü district of Kastamonu province.

Table 3. Clay Mineralogy
\begin{tabular}{|c|c|}
\hline Element & Weight $(\%)$ \\
\hline $\mathrm{O}$ & 21.83 \\
\hline $\mathrm{Mg}$ & 1.87 \\
\hline $\mathrm{Al}$ & 8.67 \\
\hline $\mathrm{Si}$ & 38.49 \\
\hline $\mathrm{Nb}$ & 5.21 \\
\hline $\mathrm{K}$ & 2.06 \\
\hline $\mathrm{Ca}$ & 14.95 \\
\hline $\mathrm{Fe}$ & 6.93 \\
\hline
\end{tabular}

Mixing Water; For the mixing water used in the production of samples, drinking water of the mains water of Boyabat district of Sinop province was used.

\subsection{Method}

Production of Brick Samples; The soils obtained from Taşköprü district of Kastamonu province was brought to the factory site. The clay soil was rested for a month at the factory site for the disposal of the salt and carbonated content contained in it. Soil samples were taken while 
taking care not to mix plant roots into the soil. The clay soil sample has been brought to the desired sizes after the resting process has been completed. Prior to brick production, all materials were dried at $105 \pm 5{ }^{\circ} \mathrm{C}$ in drying oven until they became oven dry. Then the mixtures were prepared according to the recipe given in Table 4.

Table 4. Mixture recipe

\begin{tabular}{|c|c|c|c|}
\hline & Clay Soil (\%) & Fly Ash (\%) & Boron waste (\%) \\
\hline REF & 100 & 0 & 0 \\
\hline $10 \%$ FA & 90 & 10 & 10 \\
\hline $20 \%$ FA & 80 & 20 & 10 \\
\hline $30 \%$ FA & 70 & 30 & 10 \\
\hline
\end{tabular}

First, dry materials were mixed. Then water was added with the sprinkler method at the rate of $15 \%$. In order for the mixture to be homogeneous and not to be lumped, the dough formed by spraying water on the sample in 3 stages was constantly mixed [45].

The obtained mixture was poured into special moulds of $4 \times 4 \times 16 \mathrm{~cm}$ with the help of a manual pressure press (Figure 1a). The samples removed from the moulds were dried for 24 hours in semi-open space and then for 24 hours in the drying oven at $100{ }^{\circ} \mathrm{C}$ in order to avoid cracking during baking (Figure $1 \mathrm{~b}$ ).

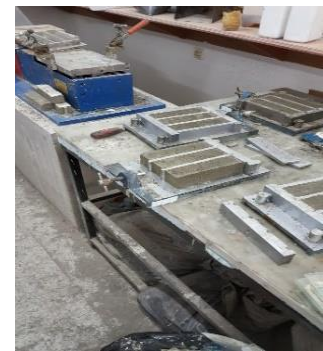

a

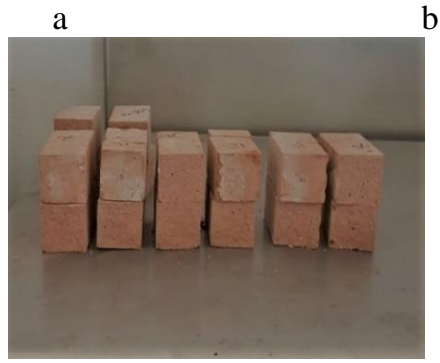

c

Figure 1. a) Pouring the samples into the moulds, b) Keeping the samples in a semi-open space, c) Bringing the samples to room temperature

After drying, the samples were baked at 3 different temperatures: 800,900 and $1000{ }^{\circ} \mathrm{C}$. After the baking process is completed, the samples are provided to reach room temperature (Figure 1c).

Experiments Applied to Samples; Dry unit volume weight, water absorption, porosity, freeze-thaw effect, determination of thermal conductivity in solid bodies were conducted for determination of physical properties of brick samples with fly ash and boron waste additive. In order to determine the mechanical properties of brick samples, compressive strength and flexural strength tests were applied.

\section{RESEARCH RESULTS AND ASSESSMENT}

\subsection{Dry Unit Volume Weight}

In Figure 2, dry unit volume weights of reference, $10 \%$ boron waste and fly ash doped samples were compared. When the figure is examined, it is seen that the dry unit volume weights of the samples vary between 1.71-1.88 $\mathrm{g} / \mathrm{cm} 3$. It was observed that dry unit volume weights decreased as the amount of fly ash increased in brick samples. The reason for this is thought to be that the density of fly ash being less than clay. There is no limitation for the unit volume weight of the bricks at TS 705 [46]. However, in order to reduce the total weight of the building, the use of bricks with less unit volume weight will decrease the dead load of the building.

Dry Unit Volume Weight $\left(\mathrm{g} / \mathrm{cm}^{3}\right)$

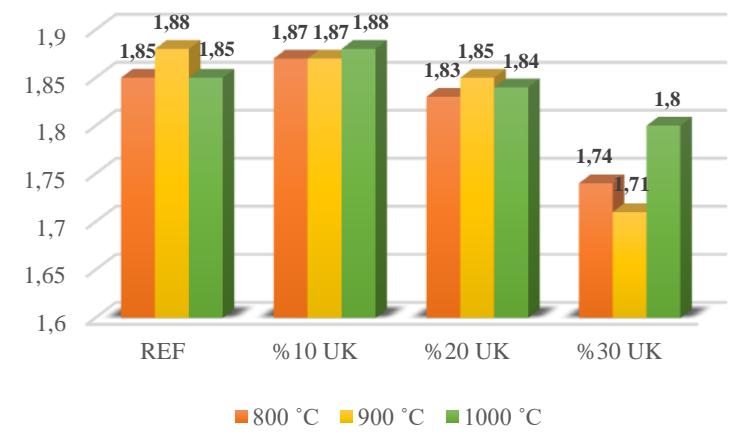

Figure 2. Dry unit volume weight values of samples

\subsection{Water Absorption (Weight)}

Water absorption is linked to the volume of open pores (cavities) that are associated with the surface of the samples. As the sintering process continues, the cavities on the brick surface turn into a round form and become smaller compared to the solid form. After the sintering process, the cavities become disconnected with the outer surface and closed. At temperatures above $900{ }^{\circ} \mathrm{C}$, sintering occurs in a fast and glassy phase. The obtained glassy phase closes the pores and disconnects them from other pores. This situation can be explained as the increase in temperature causes the decrease in the amount of water absorption [47].

When the water absorption values of brick samples is examined, it is seen that the water absorption rate decreases with increasing temperature in general. With the increase in fly ash added rates, it is observed that there is also an increase in water absorption rates. It is observed that the amount of water absorption is high at low temperature $\left(800{ }^{\circ} \mathrm{C}\right)$ and the amount of water absortion increases as the fly ash contribution rate increases. More water absorption at $800{ }^{\circ} \mathrm{C}$ is thought to be due to insufficient sintering (Figure 3). According to TS 705 standard, the water absorption rate of brick material should be $18 \%$ maximum. It is observed that the samples produced within the scope of the study are below this value. 


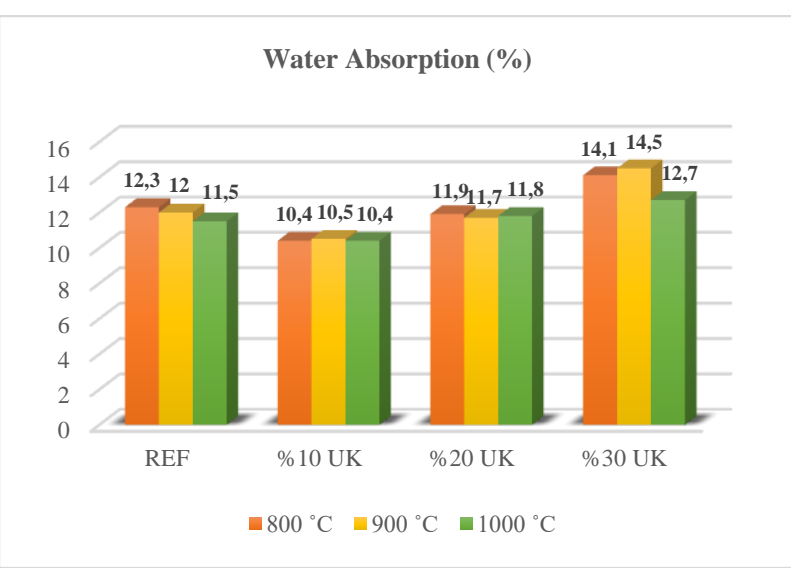

Figure 3. Water absorption values of samples

\subsection{Porosity}

When the porosity values of the brick samples are examined in Figure 4, it is seen that the reference sample is $35 \%$ at $800{ }^{\circ} \mathrm{C}, 28,6 \%$ at $900{ }^{\circ} \mathrm{C}$ and $27,2 \%$ at 1000 ${ }^{\circ} \mathrm{C}$. It is observed that a decrease in porosity amounts occurred with an increase in the baking temperature of the samples. The reason for this is thought to be that sintering at low temperature does not occur adequately, and as the temperature increases, the glassy phase ratio within the brick increases, causing it to decrease the porosity value. Also it was found that the use of fly ash at the rate of $10 \%$ and boron waste at a rate of $10 \%$ reduced porosity values, fly ash at a rate of $20 \%$, boron waste at the rate of $10 \%$. Fly ash at a rate of $30 \%$, boron waste at a rate of $10 \%$ have been determineted to increase porosity value. The reference sample baked at $800{ }^{\circ} \mathrm{C}$ with a ratio of $35 \%$ has the highest porosity, while the sample with $10 \%$ fly ash baked at $1000{ }^{\circ} \mathrm{C}$ with a ratio of $23,5 \%$ is observed to have the lowest porosity.

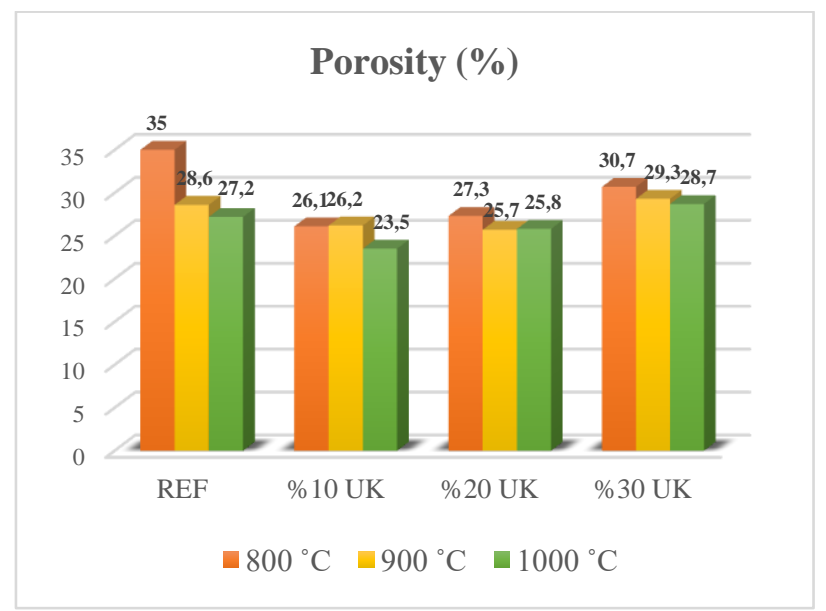

Figure 4. Porosity values of samples

\subsection{Effect of Freeze-Thaw on Compressive Strength}

Boron waste and fly ash doped brick samples were subjected to freeze-thaw test and compressive strength test was also applied on the samples. The effect of freeze-thaw on compressive strength of doped samples was determined according to the data obtained.
No dispersal event occurred in any sample after the experiment. When the samples given in Figure 5 are examined, it is seen that the highest value was obtained from the reference sample baked at $1000{ }^{\circ} \mathrm{C}$. When all samples were examined, it was determined that the best results were obtained from samples baked at $1000{ }^{\circ} \mathrm{C}$. In addition, the effect of freeze-thaw on pressure decreased as the amount of fly ash increased. The lowest results were obtained from samples baked at $800{ }^{\circ} \mathrm{C}$.

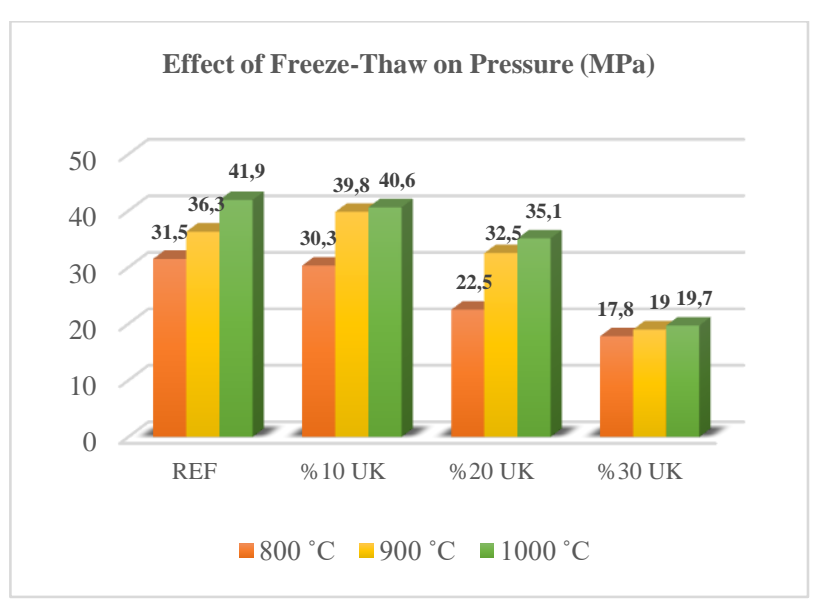

Figure 5. The values about the effect of freeze-thaw on pressure of samples

\subsection{Determination of Thermal Conductivity in Solid Bodies}

The thermal conductivity values of the brick samples are presented in Figure 6. On the graphic, the highest thermal conductivity was found to belong to the reference sample baked at $0.94 \mathrm{~W} / \mathrm{mK}$ and $800{ }^{\circ} \mathrm{C}$. When the samples were examined one by one, it was determined that the increase in temperature lowered the thermal conductivity. The increase in the amount of fly ash used in the samples resulted in a decrease in the thermal conductivity of the samples. The best result was obtained from $30 \%$ fly ash $+10 \%$ boron waste substituted samples baked at $1000{ }^{\circ} \mathrm{C}$. This is due to the fact that fly ash and boron waste are more hollow, light and low density than clay.

It has been reported that the thermal conductivity of brick building materials varies between $0.50-0.96 \mathrm{~W} / \mathrm{mK}$ in TS 825 standard. It was observed that the data obtained as a result of the experiment conducted within the scope of the study was even lower among these values. 
Determination of Thermal Conductivity of Solid Bodies $(\mathrm{W} / \mathrm{mK})$

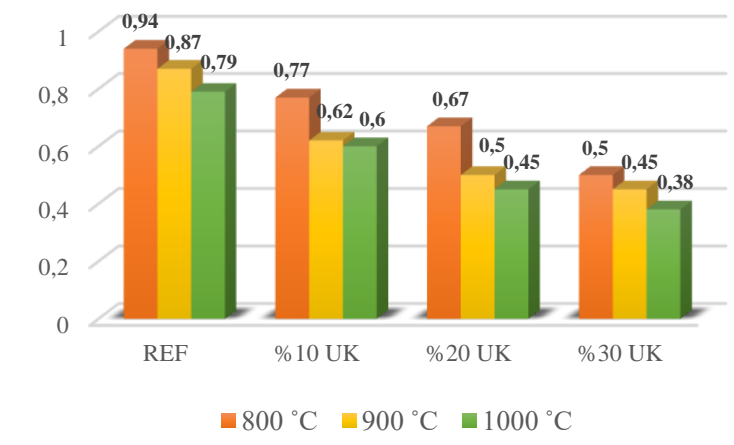

Figure 6. Thermal conductivity values of solid bodies

\subsection{Compressive Strength}

The compressive strength, which is the most important feature of the brick, is an important parameter used in order to meet the engineering quality of the building materials. Therefore, it is important to determine the compressive strength of the brick [48].

The compressive strength values of the produced brick material are presented in Figure 7. On the graphic, it is seen that the best results belong to the reference sample. The highest value was obtained from brick samples baked at $1000{ }^{\circ} \mathrm{C}$ in the reference sample. When the doped samples are examined, the best result is obtained with $10 \%$ fly ash and $10 \%$ boron waste. With the increase in the amount of fly ash, a decrease in compressive strength occurs. When the baking temperature is considered, the compressive strength of the samples is increased by increasing of the temperature. The lowest compressive strength value was obtained at $800 \mathrm{oC}$ with $19.7 \mathrm{MPa}$ and with the addition of $10 \%$ boron waste $30 \%$ fly ash.

\section{Compressive Strength(MPa)}

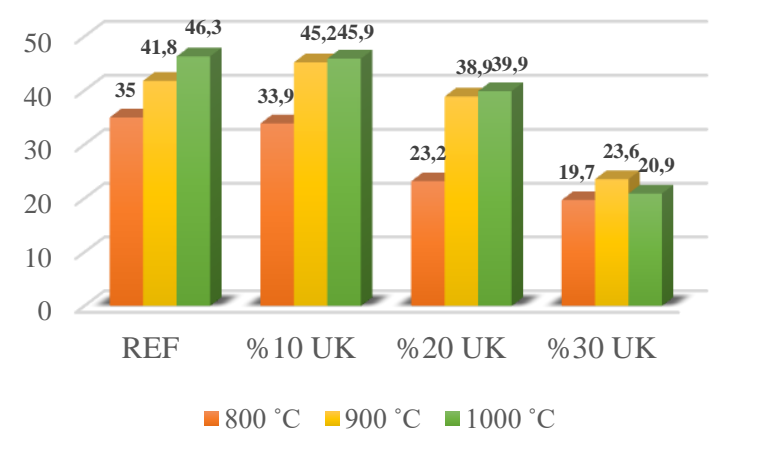

Figure 7. Compressive strength values of samples

\subsection{Flexural Strength}

When the flexural strength values of the brick sample given in Figure 8 were examined, it was observed that there is an inverse ratio between the amount of fly ash and the flexural strength values. In other words, the increase in the amount of fly ash has resulted in a decrease in flexural strength. The highest value was obtained from reference sample baked at $6.67 \mathrm{MPa}$ and $1000{ }^{\circ} \mathrm{C}$, while the lowest value was obtained from sample doped with $30 \%$ fly ash, $10 \%$ boron waste baked at $800{ }^{\circ} \mathrm{C}$ with $2.83 \mathrm{MPa}$.

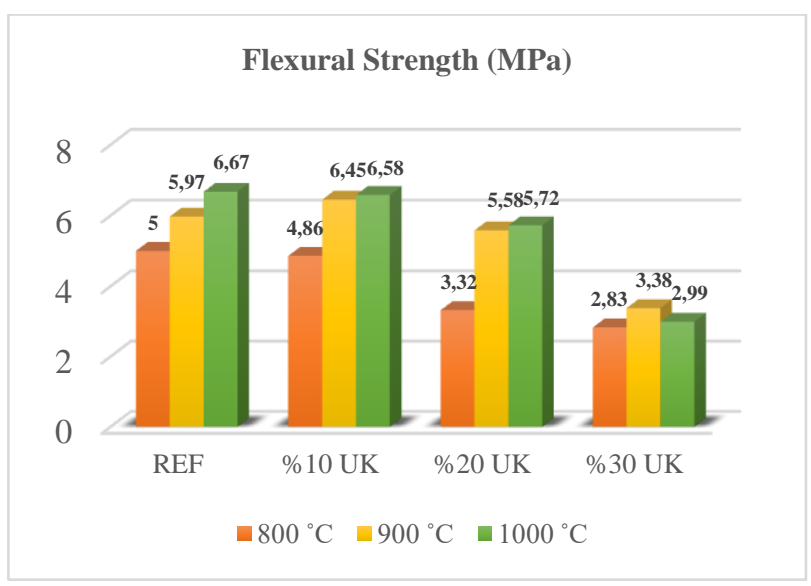

Figure 8. Flexural strength values of samples

\section{CONCLUSION AND RECOMMENDATIONS}

In the study, boron waste, which is industrial waste, was kept constant at a rate of $10 \%$ and bricks were produced by adding fly ash into the clay soil at certain ratios. The prepared semi-finished product was baked at 800, 900 and $1000{ }^{\circ} \mathrm{C}$. Physical and mechanical experiments were performed on the brick samples and the results were presented in items.

When the results obtained from all physical and mechanical tests are evaluated; It was determined that by firing the samples at high temperatures, porosity and water absorption values decreased, dry weight per unit of volume values increased, compressive strengths increased and thermal conductivity values decreased as a result of freeze-thaw. According to these results, considering the tests performed at 3 different temperatures and the cost, it was concluded that the optimum cooking temperature was 900 degrees.

When the effect of FA and boron wastes is evaluated; It was determined that as the amount of FA increased, the dry weight per unit of volume values decreased and the water absorption and porosity values increased. For these reasons, it has been determined that as the amount of FA increases, not only the compressive strength due to freeze-thaw, but also normal compressive strengths and flexural strengths decrease. However, the increase in the amount of FA created a tendency to decrease the thermal conductivity due to the increase of porosity and increased the thermal insulation property of the material. According to all these results, even if the physical properties deteriorate as the amount of FA increases and the mechanical properties decrease accordingly, the results obtained meet the minimum requirements that should be in the standard. Therefore, using 30\% FA, $10 \%$ boron waste additive ratio, waste evaluation and reduction of disposal costs, reduction of environmental 
pollution, etc. it has been concluded that it will provide various advantages.

\section{REFERENCES}

[1] Rahman, M. E., Ong, P. J., Nabinejad, O., Islam, S., Khandoker, N. A. N., Pakrashi, V. \& Shorowordi, K. M. Utilization of blended waste materials in bricks, Technologies. 2018; 6(1): 20.

[2] Houben, H. \& Guillaud, H. Earth construction: A Comprehensive Guide, London; 1994.

[3] Niroumand, H., Zain, M.F.M. \& Alhosseini, S.N. The influence of nano-clays on compressive strength of earth bricks as sustainable materials. Procedia - Social and Beh. Sci. 2013; (89): 862865.

[4] Zhao, Y., Gao, J., Liu, C., Chen, X., XuSong, Z. The particle-size effect of waste clay brick powder on its pozzolanicactivity and properties of blended cement. J. Cle. Prod. 2020; 242 118521: 1-10.

[5] Abjaghou, H., Bourret, J., Tessier-Doyen, N., Fassier, M., Bruneaux, M.A., Lacanilao, A. et al. Incorporation of Wooden Furniture Wastes in Fired Clay Bricks for Improved Thermal Insulation: A Feasability Study. Waste Bio. Val. 2020; 11: 69436951.

[6] Shakir, A. A., Naganathan, S. K. \& Mustapha, K. N. B. Development of bricks from waste material: A review paper. Aust. J. Bas. and App. Sci. 2013; 7(8): 812-818.

[7] More, A., Tarade, A. \& Anant, A. Assessment of suitability of fly ash and rice husk ash burnt clay bricks. Int. J. Sci. Res. Pub. 2014; 4(7): 1-6.

[8] Pawar A. \& Garud D. Engineering properties of clay bricks with use of fly ash. Int. J. Res. Eng. and Tech. 2014; 3(9): 75-80.

[9] Kumar R. \& Hooda N. An experimental study on properties of fly ash bricks. Int. J. Mec. Eng. Rob. Res. 2014; 2 (9): 56-67.

[10] Chidiac, S.E. \& Federico L.M. Effects of waste glass additions on the properties and durability of fired clay brick, Canadian J. Civ. Eng. 2007; 34(11): 1458-1466.

[11] Chen Y., Zhang Y., Chen T., Zhao Y. \& Bao S. Preparation of eco-friendly construction bricks from hematite tailings, Const. and Buil. Mat. 2001; 25 (4): 2107-2111.

[12] Djangang C., Kamseu E., Elimbi A., Lecomte G. \& Blanchart P. Net-shape clay ceramics with glass waste additive, Mat. Sci App. 2014; 5: 592-602.

[13] Kazmi, S.M.S., Abbas, S., Saleem, M.A., Munir, M.J. \& Khitab, A. Manufacturing of sustainable clay bricks: Utilization of waste sugarcane bagasse and rice husk ashes. Const. and Buil. Mat. 2016a; 120: 29-41.

[14] Kazmi, S.M.S, Abbas, S., Munir, M.J. \& Khitab, A. Exploratory study on the effect of waste rice husk and sugarcane bagasse ashes in burnt clay bricks, J. Buil. Eng. 2016b; 7: 372-378.

[15] Çağlar H., Çağlar A., Korkmaz S.Z., Demirel B. \& Bayraktar O.Y. Comparison of the Physical and Mechanical Properties of Manually Produced Clay Bricks and Fabricated Clay Bricks Used in the
Construction of Traditional Kastamonu Houses. Firat Uni. J. Eng. Sci. 2018; 30 (2): 39-48.

[16] Tokyay M. \& Çetin B. Strength and water absorption properties of volatile culvert bricks applied with pressed steam cure. Technical Journal, TMMOB Const. Eng., Chamber Publishing. 1991; 2: 385-394. Istanbul, Turkey.

[17] Tütünlü F. \& Atalay Ü. Utilization of fly Ash in Manufacturing of Building Bricks, International Ash Utilization Symposium, Center for Applied Energy Research, University of Kentucky, Lexington, Kentucky, USA; 2001.

[18] Murathan A., Asan A. \& Abdulkerem T.A. Evaluation of environmental wastes on building materials, Gazi Uni. J. Eng. Arc. 2013; 28 (2): 409 416.

[19] Xu L., Gou W., Wang T. \& Yang N. Study on fired bricks with replacing clay by fly ash in high volume ratio, Const. Build. Mat. 2005; 19: 243 247.

[20] Bentli, İ., Uyanık, A.O., Demir, U., Şahbaz, O. Use Of Fly Ashes Of Seyitömer Thermal Power Plant As Additive Raw Material for Bricks. Turkey 19. National Mining Congress and Fair, Izmir, 2005.

[21] Abalı, S., \& Şahin, B. Investigation of the usage possibilities of thermal power plant wastes in floor tile manufacturing. Çanakkale Onsekiz Mart University, Industrial Ceramics Department Lecture Notes, 2006.

[22] Aksin, E. Evaluation of industrial wastes in brick and tile production, [Master's Thesis], İzmir: Dokuz Eylül University; 2007.

[23] Çinçin, Y. Investigation of lightweight brick production with lime additive from lignite-burning thermal power plant fly ashes. [Master's Thesis], İzmir: Dokuz Eylül University; 2015.

[24] Söylemez, M., Demir A. \& Onar, A.F. Effects of burning temperature on some physical properties of brick. Celal Bayar Uni. J. Phy. Sci. 2011; 7(2): 7180.

[25] Abbas, S., Saleem, M. A., Kazmi, S.M.S. \& Munir, M. J. Production of sustainable clay bricks using waste fly ash: mechanical and durability properties. J. Buil. Eng. 2017; 14: 7-14.

[26] Dağc1, F. Effects of different component ratios and production temperatures on the brick properties produced. [Master's Thesis], Antalya: Akdeniz University; 2018.

[27] Demir, İ., Başpınar M.S., Görhan, G. \& Kahraman, E. Preliminary investigation of the useability of Seyitömer fly ash in building brick production. Afyon Kocatepe University J. Phys. Sci, Special Issue. 2018: 131-137.

[28] Leiva C., Arenas C., Alonso-Farinas B., Vilches L.F., Peceno B. \& Rodriguez-galan $M$. Characteristics of fired bricks with co-combustion fly ashes, J. Buil. Eng. 2016; 5: 114-118.

[29] Çiçek, T. \& Çinçin, Y. Use of fly ash in production of light-weight building bricks. Const. Buil. Mat. 2009; 94: 521-527.

[30] Bouzoubaa, N. \& Lachemi M. Self-compacting concrete incorporating high volumes of class fly 
ash: preliminary results, Cem. and Conc. Res. 2001; 31(3): 413-420.

[31] Pawar A, Garud D. Engineering properties of clay bricks with use of fly ash. Int. J. Res. Eng. Tech. 2014; 3 (9): 75-80.

[32] Shakir, A. A., Naganathan, S. K., Mustapha, K. N. B., (2013). Development Of Bricks From Waste Material: A Review Paper. Australian Journal of Basic and Applied Sciences, 7(8), 812-818.

[33] Li, Y. \& Lin, Y. Compacting Solid Waste Materials Generated in Missouri to Form New Products. Final Technical Report to the Solid Waste Management Program. Missouri Department of Natural Resources (MDNR) (Contact no. MDNR 00038-1), Capsule Pipeline Research Center, University of Missouri-Columbia, USA, 2002.

[34] Kumar, S. A perspective study on fly ash-limegypsum bricks and hollow blocks for low cost housing development. Cons. and Buil. Mat. 2002; 16(8): 519-525.

[35] İnce, A.S. Investigation of the use of coal char and boron in brick structure, [Master's Thesis], Kütahya: Dumlupınar University; 2019.

[36] Kavas, T., Önce, G. The Useability of Concentrator Wastes of Etibor Kirka Borax Plant as Melting Element In Press Brick Production. http://www.maden.org.tr/resimler/ekler/41c377c73 c0efed_ek.pdf.

[37] Demir, İ. \& Orhan, M. (2018). Evaluation of Boron Wastes in Building Material Production. http://www.maden.org.tr/resimler/ekler/5f441cd5f4 3eb2f_ek.pdf.

[38] Aydin, O. Investigation of the use of thermal power plant waste ash in building brick production. [Master's Thesis], Afyonkarahisar: Afyon Kocatepe University; 2007.

[39] Ertaş, N.Y. Evaluation of some waste materials in brick production. [Master's Thesis], Kütahya: Dumlupınar University, 2017.

[40] Şahin, Ş.E. Investigation of the use of raw and calcined colemanite wastes in brick construction. [Master's Thesis], Kütahya: Dumlupınar University, 2008.

[41] Batar, T. \& Köksal, N.S. Production and Characterization of Waste Boron, Waste Paper and Perlite Additive Plaster Material. Ecology Journal. 2009; 18 (72): 1-9.

[42] Aldakshe AMA, Çağlar H, Çağlar A, Avan Ç. The Investigation of Use as Aggregate in Lightweight Concrete Production of Boron Wastes of EskişehirKirka Region, Civil Eng. J. 2020;7(6):1328-1335.

[43] Çimen S, Çağlar H, Çağlar A, Can Ö. Effect of Boron Wastes on the Engineering Properties of Perlite Based Brick, Turkish J. of Nature and Sci. 2020;9(2):50-56.

[44] Çağlar, A. Experimental research on improving the properties of clay bricks used in traditional Kastamonu houses with the contribution of boron waste. [Doctoral Thesis], Konya: Selçuk University; 2018.

[45] Gençel, G. Characteristics of fired clay bricks with pumice additive. Ene. and Buil. 2015; (102): 217224.
[46] TS 705, (1985). Solid Bricks-Filled For Walls and With Vertical Holes. Turkish Standards Institute, Ankara.

[47] Milheiro F.A.C., Freire, M.N., Silva, A.G.P \& Holanda, J.N.F. Densification Behaviour of a Red Firing Brazilian Kaolinitic Clay. Ceramics Int. 2005; 31: 757-763.

[48] Mahllawy, M.S. Characteristics of Acid Resisting Bricks Made From Quarry Residues and Waste Steel Slag. Const. and Buil. Mat. 2008; 22: $1887-$ 1896. 